\title{
Institutions and FDI: evidence from developed and developing countries
}

\author{
Samina Sabir ${ }^{r^{*}}$ (D) Anum Rafique ${ }^{1}$ and Kamran Abbas $^{2}$
}

\author{
* Correspondence: \\ samina.sabir78@gmail.com \\ ${ }^{1}$ Kashmir Institute of Economics, \\ University of Azad Jammu \& \\ Kashmir, Muzaffarabad, Azad \\ Kashmir, Pakistan \\ Full list of author information is \\ available at the end of the article
}

\begin{abstract}
This study investigates the impact of institutional quality on Foreign Direct Investment (FDI) inflows using panel data for low, lower-middle, upper-middle and high-income countries for the sample period of 1996-2016 using the system Generalized Method of Moments (GMM). The empirical results confirm that institutional quality has a positive impact on FDI in all group of countries. The magnitude of the coefficients of control of corruption, government effectiveness, political stability, regulatory quality, rule of law, and voice and accountability for FDI inflows are greater in developed countries than in developing countries. We conclude that institutional quality is a more important determinant of FDI in developed countries than in developed countries. However, GDP per capita, agriculture value-added as a percentage of GDP, and inflation influence FDI inflows negatively in developed countries, while GDP per capita, trade openness, agriculture value-added as a percentage of GDP, and infrastructure have positive and statistically significant impacts on FDI inflows in developing countries. Trade openness as a percentage of GDP and infrastructure positively affect FDI in developed countries. From our analysis, we infer that institutional quality is a more important determinant of FDI in developed countries than in developing countries.
\end{abstract}

Keywords: Institutional quality, FDI, Economic development, Panel data

JEL classifications: $\mathrm{O} 1, \mathrm{O} 4, \mathrm{O} 43, \mathrm{E} 62, \mathrm{O} 57$

\section{Springer Open}

\section{Introduction}

The traditional neoclassical growth model claims that differences in countries' per capita incomes are due to differences in their capital accumulation, which are in turn due to their differing saving rates. Therefore, differences in capital accumulation are due to differences in countries' saving rates (Solow 1956; Koopmans 1965). Furthermore, developing countries are characterized by low per capita income, poverty, unemployment, high population growth and low savings rates. Certainly, low levels of savings and investments create savings-investment gaps that have negative impacts on economic growth and development.

Foreign direct investment (FDI) helps to fill the gap between savings and required level of investment (Sabir and Khan 2018). Globalization increased the importance of FDI worldwide and endogenous growth theories emphasize that FDI is a key determinant of economic growth because it is a source of technological transfer from developed

(c) The Author(s). 2019 Open Access This article is distributed under the terms of the Creative Commons Attribution 4.0 International License (http://creativecommons.org/licenses/by/4.0/), which permits unrestricted use, distribution, and reproduction in any medium, provided you give appropriate credit to the original author(s) and the source, provide a link to the Creative Commons license, and indicate if changes were made. 
countries to developing countries (Chenaf-Nicet and Rougier 2016). FDI can directly and indirectly reduce unemployment (Lipsey 2001) and increases productivity by improving the skills and knowledge of workers in the host country.

Since 1990, competition enhanced among developed countries and developing countries to attract FDI inflows in term of reducing taxes and providing subsidies. Many developing countries adopted policies to facilitate FDI inflows and monitor FDI operations (World Bank 2013). Such as financial sector adjustment program, structural adjustment programs, economic recovery programmes and economic partnership agreements (Asamoah et al. 2016). Since 1990, FDI increased in developing countries, including among members of the South Asian Association of Regional Cooperation (SAARC), the Association of Southeast Asian Nations (ASEAN), Sub-Saharan African countries and Central Asian countries. Perhaps these developing countries are benefitting from FDI inflows, such as improved technology, better management skills and increased capital accumulation, exports, employment, higher productivity, and economic growth.

Dunning (1988) proposed the eclectic paradigm theory that decision of a foreign investor to invest in a host country depends on the size of the firm, administration and management systems, labor and transportation costs, government policies, as well as institutions and political stability. Foreign investors may be more concerned about risk and return when they enter the foreign markets (Fedderke and Romm 2006).

The relationship between institutions and economic performance has attracted attention from researchers and policy makers for the last few decades. North and Thomas (1973) emphasize that economic factors such as capital accumulation, per capita income, and innovation are not the only factors that create differences in a country's economic growth and development; systematic differences in institutional quality are also responsible for those differences. For example, North and South Korea have the same economic attributes but differ in their economic outcomes (for example, South Korea has a higher per capita GDP than North Korea does) due to the differences in their institutions (Acemoglu et al. 2006). Indeed, economic institutions are important because they shape the behavior of economic actors and stakeholders (Sabir and Zahid 2012). In countries with secure well-protected property rights, people are incentivized to make domestic and foreign investments that boost economic growth. Otherwise, investment and growth lag behind.

Poor institutions impede FDI and can act like a tax, thus increasing the cost of FDI (Buchanan et al. 2012). Investors are unwilling to invest in countries where institutions encourage corruption, nepotism and red tape because these factors increase the cost of doing business (Mengistu and Adhikary 2011).

Harms and Ursprung (2002) find that foreign investors invest in countries with strong democratic structures, while autocratic societies often experience policy reversal and attract less FDI. Some studies find that institutional quality positively and significantly impacts FDI inflow in Asia and Latin America (Gani 2007), SAARC, Central Asian countries and the ASEAN region (Ullah and Khan 2017). Lucke and Eichler (2016) estimate the impact of institutional and cultural determinants of FDI in developing countries and find a positive association 
between institutions and FDI in developing countries and that foreign investors prefer to invest in countries that are politically unstable and have less diverse societies. Peres et al. (2018) analyze the impact of institutional quality on FDI inflows in developed and developing countries using corruption and the rule of law as measures of institutional quality, and find that institutions have an insignificant impact on FDI in developing countries due to the weak structure of institutions. Moreover, institutional quality has a positive and significant impact on FDI in developed countries. Other studies analyze the impact of institutions on FDI inflows at various stages of development. Therefore, good quality institutions in the host country are a precondition for attracting FDI inflows into that country. This study examines the impact of the indicators of institutional quality (such as political stability, control of corruption, rule of law, voice and accountability, regulatory quality and government effectiveness) on inward FDI in developing and developed countries. These are indicators of three important dimensions of institutional quality: 1) political stability, 2) administrative quality, and 3) democratic accountability. We examine the separate effect of each indicator on FDI inflows in low, lower-middle, high, and upper-middle-income countries.

Institutional quality indicators are highly correlated (Globerman and Shapiro 2002; Daude and Stein 2007; Buchanan et al. 2012), and it is not possible to include all indicators in a single equation (Ullah and Khan 2017). Therefore, we construct an institutional quality index using principal component analysis (PCA). The basic purpose of using this technique is to combine the six indicators of institutional quality into a single variable that duplicates the original data with minimal loss of information. The empirical analysis uses panel data of 59 and 89 developing and developed countries, respectively for 1996-2016. To avoid heteroscedasticity, autocorrelation, omitted variable bias and endogeneity problems, we use the system Generalized Method of Moments (GMM).

This paper offers three contributions to the literature. First, the results indicate that the effect of institutions on FDI inflows varies across countries. To analyze the impact of institutions on FDI, we separate developing countries into low and lower-middle-income countries, and developed countries into upper-middle and high-income countries. Second, we examine the impact of each indicator of institutional quality on FDI inflows separately for both developing and developed countries. Third, we construct an institutional quality index to study its impact on FDI.

The remainder of the study proceeds as follows: Section "Theoretical frame work" provides the theoretical background on institutions and foreign direct investment. Section "Methodology and data" presents the methodology and data. Section "Results and discussion" discusses the empirical results, and section "Conclusion" concludes.

\section{Theoretical framework}

North (1990) defines institutions as human invented constraints consisting of structural, economic, political and social issues. Indeed, institutions represent the formal and informal rules of the game in which different players and economic actors interact and perform actions to maximize their profits and returns. 
According to North (1990), good institutions affect economic activities through different channels such as by reducing the transaction, manufacturing and production costs. Moreover, good quality institutions help reduce the cost of doing business, which increases profitability. However markets with poor institutions take up more time and resources for monitoring. When property rights are poorly protected and contract enforcement is difficult, the risk premium is high and economic activity is slower. International investors hesitate to invest in such a risky and unconducive environment. By contrast, a risk-free environment is a good location for the source country and good institutions also lead to better FDI utilization. Lucas (1993) suggests that in emerging economies, institutional factors, as compared to purely economic factors, play an important role in attracting inward FDI.

In summary, the host country's institutional quality affects profitability, and institutionally strong countries can attract foreign investors by offering high returns. Dunning (1998) expands the concept of locational advantage by adding institutional factors along with economic factors. He argues that foreign investors prefer locations that offer the best economic and institutional facilities. Hence, foreign investors' decisions depend on the rate of return based on sound institutions and other macroeconomic indicators.

Based Dunning's eclectic paradigm theory and North's institutional theory, inward FDI depends on market size, natural and human resources, efficiency seeking and the institutional quality of the host country. We can algebraically write this relationship as

$$
F D I=f(\text { Market size, macroeconomic stability, Institutions })
$$

where FDI is foreign direct investment, market size is an important determinant of FDI in the host country and is proxied with GDP per capita, macroeconomic stability indicates the economic situation of the host country that affects FDI measured by inflation. Inflation indicates the internal economic tension and ability of the central bank and government to control the money supply and balance the budget (Schneider and Frey 1985; Buchanan et al. 2012). Some argue that a higher rate of inflation leads to lower FDI (Bruno 1993; Buchanan et al. 2012). According to the theoretical literature, institutional quality positively impacts economic growth (North 1990; King and Levine 1993; Knack and Keefer 1995; Mauro 1995; Acemoglu and Verdier 1998; Ali et al. 2010). However, some studies examine the effects of institutional quality on FDI with a focus on the rule of law, property rights enforcement, control of corruption, voice and accountability, and government effectiveness. These studies find that weak institutions are negatively associated with FDI (Bénassy-Quéré et al. 2007; Buchanan et al. 2012).

\section{Methodology and data}

\section{Econometric model}

Based on theoretical background, we use the following empirical model to analyze the impact of institutions on FDI:

$$
Y_{i t}=\alpha+\beta_{i} X_{i t}+\gamma_{i} Z_{i t}+U_{i t}
$$

where $Y_{i t}$ is the log of FDI inflows, $X_{i t}$ are vectors of the variables of interest of country 
$\mathrm{i}=(1,2,3, \ldots, \mathrm{N})$ during period $\mathrm{t} t=(1,2,3, \ldots, \mathrm{T})$. The variables of interest consist of indicators of political institutional quality, $Z_{i t}$ are the vectors of control variables such as inflation, trade openness, GDP per capita, value added share of agriculture as a percentage of GDP, and infrastructure measured as mobile phone subscription per 100 people, and $U_{i t}$ is the error term.

FDI is the dependent variable. Prior empirical studies use different proxies of FDI, and in line with other studies, we use FDI inflows, which is the log of net inflow of FDI in current U.S. dollars. We use inflation as a proxy of macroeconomic instability and economic tension, as there is a negative relationship between inflation and FDI.

It is widely believed that the host country's level of development is an important determinant of inward FDI. As the level of development increases, the population's ability to purchase goods and services increases, which motivates foreign investors to invest. GDP per capita captures the level of development. Moreover, trade openness is a vital factor in promoting inward FDI because foreign investors prefer free trade over restricted trade. As the latter increases the cost of doing business, increases which discourages foreign investment. Theoretically, there is a positive relationship between trade openness and FDI (Kravis and Lipsey 1982; Culem 1988; Shah and Khan 2016). We use trade openness as a proxy of market-seeking FDI. Good infrastructure can attract greater FDI because it reduces operational costs (Khadaroo and Seetanah 2010). We use infrastructure as a proxy of efficiency-seeking FDI. We also include the value-added share of agriculture in GDP as an explanatory variable because FDI is an important source of investment in agriculture and can enhance agricultural productivity by introducing new technology (Tondl and Fornero 2010). In line with other studies, we use mobile phone subscriptions per 100 people as a proxy of infrastructure. Theoretically, there is positive relationship between infrastructure and inward FDI. Efficiency-seeking investment targets with relatively low costs of transport and communication (Dunning 2006).

We consider six indicators of institutional quality: control of corruption, political stability, rule of law, regulatory quality, voice and accountability, and government effectiveness (Kaufmann et al. 2007) to examine their impact on FDI inflows in developing and developed countries. Corruption refers to the use of public power for personal gain and covers a broad range of human actions. We use control of corruption as a proxy of institutional quality. Theoretically, there is a positive relationship between control of corruption and inward FDI. Political stability is an important factor that ensures the inflow of FDI. FDI is a long-term investment activity, and every type of threat discourages FDI inflows. Multinational corporations (MNCs) avoid FDI in cases of political instability due to high risk, and switch to risk-free countries (Meier 2006). By contrast, the rule of law encourages inward FDI. Rules and laws are sets of agreements by which countries implement FDI policies and that protect future returns (Hoff and Stiglitz 2005). The rule of law discourages market-unfriendly policies and minimizes risk. Regulatory quality boosts inward FDI by introducing market-friendly policies such as price controls, government intervention, and free movement of capital (Fazio and Talamo 2008). Regulatory quality captures the government's ability to 
formulate and implement sound policies and regulations that promote economic development. Voice and Accountability have positive relations with FDI: through voice and accountability, a country's citizens can enjoy many freedoms such as freedom of expression, freedom of association, and free media. Furthermore, when citizens select their government, they are in a position to reject corrupt governments. Voice and accountability are together responsible for providing a risk-free climate for domestic and foreign investors (Inter-American Development Bank 2001; Saadatmand and Choquette 2012). Government effectiveness captures the quality of public and civil service and the degree of its independence from political pressure (Buchanan et al. 2012).

We examine the impact of each indicator of institutional quality on FDI controlled with other macroeconomic variables. All these measures of institutional quality are highly correlated, so it is inappropriate to use all of them in a single equation (Globerman and Shapiro 2002). Appendix 1 reports the correlation matrix of the six governance indicators, which indicates a high correlation among variables.

Therefore, we use PCA to construct a composite index of institutions. We extract the first principal component of the six proxies of institutional quality using factor analysis (Globerman and Shapiro 2002; Buchanan et al. 2012), which we refer to as the institutional quality index. This index ranges from -0.659 to +2.48 for high-income countries, -2.894 to 2.277 for upper-middle-income countries -2.351 to 1.918 for lower-middle-income countries and -0.436 to 0.754 for low-income countries. This index implies that institutions are more developed in developed countries than in developing countries.

To examine the impact of institutions on inward FDI, this paper used panel data of 20 low-income, 39 lower-middle-income, 44 upper-middle-income countries and 45 high-income countries for 1996 to 2016. We include low-income and lower-middle-income countries within the category of developing countries, and upper-middle income and higher-income countries within the set of developed countries. We select the countries and sample period according to the data ${ }^{1}$ availability.

The main sources of data are the World Development Indicators (WDI) and the World Governance Indicators (WGI). Data on inflation, trade openness, mobile phone subscriptions per 100 people, GDP per capita, and value-added share of agriculture as a percentage of GDP were obtained from the WDI.

We obtained data on the institutional variables control of corruption, voice and accountability, government effectiveness, political stability, rule and law, and regulatory quality from WGI. ${ }^{2}$

\section{Estimation methods}

To investigate the impact of institutions on FDI, we estimate the following regression:

$$
Y_{i t}=\alpha_{\circ}+\alpha_{i} Y_{i t-1}+\beta_{i} X_{i t}+\gamma_{i} Z_{i t}+U_{i t}
$$

where $\alpha \beta$ and $\gamma$ are the parameters we estimate. We cannot estimate this fixed effect regression using the least square dummy variable (LSDV) method if linear regression assumptions are not satisfied; for example, the means of the random term (U) should be zero and the covariance between $U$ and $\mathrm{X}$ should be zero $\operatorname{cov}\left(\mathrm{X}_{\mathrm{it}}, \mathrm{U}_{\mathrm{it}}\right)=0$.

However, the literature on institutions and FDI indicates an issue with endogeneity in the institutional variable (Ali et al. 2010; Peres et al. 2018). Using LSDV method will 
result in biased and inconsistent estimators. We therefore address this problem by using system GMM, or instrumental variable method (Arellano and Bond 1991; Blundell and Bond 1998). The dynamic equation is

$$
\Delta y_{i t}=\alpha_{0}+\omega \Delta \ln y_{i, t-1}+\beta \ln X_{i t}+\gamma \ln Z_{i t}+\eta_{i}+v i
$$

System GMM is a combination of level and difference dynamic equations that improves on difference-GMM because it both supplements the equation in the first differences with the equation in levels and allows for the correction of measurement errors in the other regressors (Blundell and Bond 1998). The prerequisite for system GMM are that the autocorrelation at the first order autoregressive AR(1) process should be significant and autocorrelation at the second order autoregressive AR(2) should be insignificant.

Legal origin is the significant determinant of institutional quality and size of the financial market (Buchanan et al. 2012). For example, legal enforcement can secure property rights and quality enforcement of legal rights attracts FDI. Moreover, these rules vary across countries by legal origin, depending on whether the origin is English, French, Scandinavian, or German. However, the primary legal systems consist mainly of French civil law and English common law (David and Brierley 1985). Some argue that countries with institutions based on French civil law tend to offer protection to the fragile investor and have smaller capital markets, whereas common law countries offer strong protection and have larger capital markets (La Porta et al. 1997). We use legal origin as an instrument for institutional variables, lagged values of explanatory variables as instruments for the difference equation, and explanatory variables with lagged difference as instruments for the level equation. We use a maximum of five lags of the explanatory variables as instruments until the results pass the Sargan test.

\section{Results and discussion}

\section{Estimation results for developing countries}

Table 1 reports the empirical results for low and lower-middle income countries. First, we estimate our fixed effect model by employing the LSDV method and use the Wu Hausman test to check for endogeneity in the institutional variable, trade openness, lnGDP per capita, and all other explanatory variables.

The results show that trade openness positively and significantly impacts FDI inflows in both low and lower-middle-income countries. Moreover, holding all other factors constant, a one-percentage-point increase in trade openness leads to a $3.7 \%$ increase in FDI inflows in low-income countries and a $2.1 \%$ increase in lower-middle-income countries. These findings are in line with results by Furceri and Borelli (2008), Asiedu (2002), and Liargovas and Skandalis (2012). This implies that the more-open economies encourage more inflows of foreign capital than do the less-open economies. Similarly, the number of mobile phone users, and lnGDP per capita are positively and statistically significantly associated with FDI in both groups of developing countries. However, inflation impacts FDI negatively but it is statistically insignificantly. It is interesting that agricultural value-added as a percentage of GDP has a positive and statistically significant impact on FDI inflows in lower-middle-income countries, but it is statistically insignificant for low-income countries. 
Table 1 Estimation Results for Developing Countries

\begin{tabular}{|c|c|c|c|c|}
\hline \multirow[t]{2}{*}{ Variables } & \multicolumn{2}{|c|}{ Low Income Countries } & \multicolumn{2}{|c|}{$\underline{\text { Lower Middle income Countries }}$} \\
\hline & FEM & GMM & FEM & GMM \\
\hline $\operatorname{lnFDI}(\mathrm{t}-1)$ & & $0.471^{\mathrm{a}}(0.000)$ & & $0.596^{\mathrm{a}}(0.000)$ \\
\hline Trade & $0.005(0.927)$ & $0.037^{\mathrm{b}}(0.020)$ & $0.074^{\mathrm{a}}(0.000)$ & $0.021^{\mathrm{a}}(0.000)$ \\
\hline InMobile & $0.306(0.285)$ & $0.384^{c}(0.060)$ & $0.078(0.449)$ & $0.096^{\mathrm{C}}(0.101)$ \\
\hline LnGDP per capita & $10.776(0.191)$ & $15.527^{b}(0.023)$ & $0.841^{\mathrm{b}}(0.047)$ & $8.603^{b}(0.048)$ \\
\hline Inflation & $-0.0002(0.087)$ & $-0.003(0.977)$ & $-0.017(0.343)$ & $-0.008(0.567)$ \\
\hline Agriculture value added & $0.466^{\mathrm{b}}(0.011)$ & $0.043(0.248)$ & $0.101^{\mathrm{b}}(0.031)$ & $0.009^{\mathrm{a}}(0.001)$ \\
\hline Institutional Index & $0.354^{\mathrm{b}}(0.816)$ & $2.027^{b}(0.022)$ & $0.471^{b}(0.339)$ & $2.580^{\mathrm{b}}(0.021)$ \\
\hline Constant & $45.263^{\mathrm{b}}(0.039)$ & $17.879^{\mathrm{b}}(0.044)$ & $6.254^{b}(0.048)$ & $7.658^{b}(0.018)$ \\
\hline$A R(1)$ & & 0.000 & & 0.000 \\
\hline$A R(2)$ & & 0.120 & & 0.117 \\
\hline Sargan & & 0.234 & & 0.721 \\
\hline
\end{tabular}

Note: ${ }^{a},{ }^{b}$ and ${ }^{\mathrm{c}}$ denote significance at the $1 \%, 5 \%$ and $10 \%$ levels, respectively. Parentheses show $P$-values

The institutional quality index has a positive and statistically significant effect on FDI in both group of countries. A one-standard-deviation improvement in the political institutional index leads to a 7.5-fold increase in FDI in low-income countries and a 13.20-fold increase in lower-middle-income countries. This finding implies that institutions in developing countries are improving gradually, which is attracting enormous amounts of FDI inflows.

\section{Estimation results of developed countries}

The results in Table 2 show that all control variables are significant and maintain their anticipated signs for high and upper-middle-income countries. Trade openness has a positive and statistically significant influence on FDI inflows, implying that more open countries have incentives to attract more market-seeking FDI in both groups. These findings are consistent with the previous literature (Asiedu 2002; Egger and Winner 2005; Busse and Hefeker 2007; Buchanan et al. 2012). The estimated coefficient of lnGDP per capita is negative and statistically significant in both high and upper-middle-income countries. This finding suggests that inward FDI does not have better prospects in developed countries with higher GDP per capita. One reason could be that foreign investors do not consider the level of development as a sufficient indicator when deciding whether to invest capital in developed countries because they may choose to invest in these countries due to the presence of high-quality institutions. The other reason could be that as living standard increases, the cost of doing business also increases (Buchanan et al. 2012). The coefficient of the mobile phone subscription rate is positive and statistically significant, which shows that quick dissemination of information can attract more FDI. These findings are consistent with the study of Campos and Kinoshita (2008).

Poor infrastructure in the form of less dissemination of information increases transaction costs and restrains access to both local and global markets, ultimately impeding foreign investment (Khadaroo and Seetanah 2010). The coefficient of 
Table 2 Estimation Results for Developed Countries

\begin{tabular}{|c|c|c|c|c|}
\hline & \multicolumn{2}{|c|}{ High Income Countries } & \multicolumn{2}{|c|}{ Upper Middle Income Countries } \\
\hline & $\mathrm{FE}$ & GMM & $\mathrm{FE}$ & GMM \\
\hline $\operatorname{lnFDI}(\mathrm{t}-1)$ & & $0.581^{a}(0.001)$ & & $0.387^{\mathrm{a}}(0.000)$ \\
\hline Trade openness & $0.042(0.344)$ & $0.640^{\mathrm{b}}(0.014)$ & $0.133^{\mathrm{a}}(0.000)$ & $0.221^{\mathrm{a}}(0.000)$ \\
\hline InMobile & $2.949^{b}(0.022)$ & $0.120^{b}(0.016)$ & $0.869^{\mathrm{a}}(0.000)$ & $0.003^{b}(0.022)$ \\
\hline InGDP per capita & $-6.580(0.443)$ & $-4.981^{\mathrm{C}}(0.108)$ & $-9.227^{\mathrm{a}}(0.000)$ & $-8.355^{\complement}(0.074)$ \\
\hline Inflation & $-0.346(0.252)$ & $-0.230^{c}(0.071)$ & $0.0002(0.966)$ & $-0.021(0.269)$ \\
\hline Agriculture value added & $-0.379(0.290)$ & $-0.369(0.241)$ & $-0.142(0.132)$ & $-0.120(0.115)$ \\
\hline Institutional Index & $5.774(0.141)$ & $4.853^{b}(0.019)$ & $0.911^{\mathrm{b}}(0.033)$ & $2.693^{b}(0.055)$ \\
\hline \multirow[t]{2}{*}{ Constant } & $5.674^{\mathrm{b}}(0.036)$ & $10.270^{\mathrm{a}}(0.000)$ & $7.512^{\mathrm{a}}(0.000)$ & $21.726^{\mathrm{a}}(0.002)$ \\
\hline & 0.218 & & 0.388 & 0.000 \\
\hline$A R(1)$ & & 0.041 & & 0.342 \\
\hline$A R(2)$ & & 0.222 & & 0.262 \\
\hline Sargan & & 0.357 & & 0.371 \\
\hline
\end{tabular}

inflation is negative but has an insignificant impact on FDI. This result is consistent with Egger and Winner (2005). Agriculture value-added as a percentage of GDP has a negative and statistically insignificant relationship with FDI in high and upper-middle-income countries.

The coefficient of the political institutional index is positive and statistically significant for group of countries. Therefore, our results stand out in showing that quality political institutions can attract massive FDI inflows in developed countries. The magnitude of the coefficient of the political institution index of high-income countries is greater than that of upper-middle-income countries. Overall, the magnitudes of the coefficients of the political institutional index for the groups of developed countries are higher than those for groups of developing countries.

Political institutions are a more important and significant determinant of inward FDI in developed countries than in developing countries. This could be because high-quality institutions reduce transaction and information costs, which encourages foreign investors and hence contributes to economic growth. Moreover, political stability in the country in the form of democracy also motivates investors to invest more capital in these countries.

Impact of the institutional quality indicators on FDI in developing and developed countries We also estimate the impact of each indicator of institutional quality on FDI for low-income and lower-middle-income countries separately. We report the results in Appendix 3. The effect of the control of corruption on FDI is positive in low and lower-middle-income countries, suggesting that the presence of strong institutions in the form of control of corruption in developing countries encourages investment, which increases economic growth.

Similarly, government effectiveness and regulatory quality have a positive and statistically significant impact on FDI in low and lower-middle-income countries implying that government in the form of public and civil services, which are 
independent of political pressure, encourages investment by entrepreneurs and investors. Government effectiveness in terms of the quality of public and civil services is the same in low and lower-middle-income countries. Moreover, political stability also positively affects FDI in these countries because foreign investors do not have to fear sudden policy reversal. This implies that foreign investors prefer to invest capital in host countries with stable governments, even under policy uncertainty (Alesina et al. 1996).

However, the coefficients of regulatory quality, rule of law, and voice and accountability are insignificant in both groups of developing countries. This finding implies that these indicators are weak and do not impact FDI in these host countries. Therefore, other factors determine FDI in developing countries.

Tables 10, 11, 12, 13, 14 and 15 in Appendix 3 show that institutional indicators such as control of corruption, government effectiveness, political stability, regulatory quality, rule of law, and voice and accountability have positive and statistically significant impacts on FDI in high and upper-middle-income countries. It is worth emphasizing that institutions in developed countries are stronger than in developing countries. Control of corruption has a positive and statistically significant effect on FDI in developed countries. The coefficient for this variable has a larger impact on FDI inflows in developed countries than in developing countries, suggesting that good quality institutions for controlling corruption enhance inward FDI, which leads to economic growth. Government effectiveness has a positive and statistically significant impact on attracting FDI for both groups of high-income and upper-middle-income countries. Holland and Pain (1998a, b) identify privatization (a determinant of government effectiveness) as one key determinants of FDI; as privatization increases, FDI increases.

Political stability has a positive influence on inward FDI for developed countries. In politically unstable economies, foreign investors are hesitant to invest due to fears of sudden policy reversals, while politically stable economies are ideal for foreign investors (Brada et al. 2006). Therefore, host countries should maintain a level of political stability that will boost confidence among foreign investors.

Regulatory quality plays a positive and significant role in attracting FDI in developed countries, but regulatory quality does not influence inward FDI in developing countries. This finding implies that developed countries have adopted market-friendly policies that significantly attract FDI. Moreover, the empirical results show that the rule of law also positively and statistically significantly impacts FDI in both groups of developed countries. The implication is that developed countries adopted a transparent legal system to protect property and individual rights. Therefore, stable public institutions encourage foreign and domestic investors to make long-term sustainable investments. Voice and accountability has a positive effect on FDI in developed countries but an insignificant effect in developing countries. Hence, FDI flows to democratic countries with secure freedom of speech rights and independent media.

Our overall finding is that institutional indicators have different impacts on FDI in low, middle, upper-middle, and high-income countries. Our results suggest that good-quality institutions appear to be an important factor in FDI determination in developed countries, while they have a minor effect on inward FDI in developing countries. Moreover, we find that the level of development, trade openness and other 
macroeconomic variables significantly contribute to FDI in developing countries. However, the level of development has a negative impact on FDI in developed countries, white trade openness and infrastructure positively affect FDI in these countries.

\section{Conclusion}

This study investigated the impact of institutional quality on FDI inflows by controlling the effects of inflation, GDP per capita, trade openness as a percentage of GDP, infrastructure, and agriculture value-added as a percentage of GDP in developed and developing countries. We separated developing countries segregated into low and lower-middle-income countries, and developed countries into upper-middle and high-income countries for the sample period of 1996 to 2016. We used six governance indicators as a measure of institutional quality to examine their impact on FDI. We observed high correlation among the institutional indicators, and thus constructed an institutional quality index using PCA and adopted the system GMM to address the endogeneity problem in the institutional index and other variables. We find that indicators of institutional quality such as control of corruption, government effectiveness and political stability have positive and significant impacts on FDI inflow in developing countries but that other indicators of institutional quality have positive but insignificant impacts on FDI in these countries. Moreover, all indicators of institutional quality positively and significantly affect FDI in developed countries. Our results establish that institutional quality has a greater impact on FDI in developed countries than in developing countries. We also estimated the impact of the institutional quality index on FDI in developing and developed countries. The institutional quality index has a positive impact on FDI for all groups of countries, but the magnitudes of the coefficients is larger for developed countries than for developing countries. However, lnGDP per capita, trade openness as percentage of GDP, agriculture value added as a percentage of GDP and infrastructure have positive impacts on FDI in developing countries while inflation impacts FDI negatively in these countries. Variables such as infrastructure and trade openness have a positive impact on FDI inflows in developed countries. The value-added share of agriculture as a percentage of GDP, GDP per capita and inflation all negatively impact FDI in developed countries.

Finally, compared with other relevant policy variables, institutional reform appears to be an important determinant for attracting FDI in all countries. Undeniably, institutional quality appears to be as important as macro-economy. More specifically, macroeconomic stability in terms of a low inflation rate, efficient markets in terms of institutions, trade openness, GDP per capita and better infrastructure are important determinants of FDI. Governments in developing countries can significantly promote FDI by introducing appropriate institutional reforms and macroeconomic policies.

Further we will extend this study by including economic institutions to examine their on FDI inflows in developing countries.

\section{Endnotes}

${ }^{1}$ Lists of countries provided in Appendix 2

${ }^{2}$ Table of variables and data sources is provided in Appendix 2 


\section{Appendix 1}

Table 3 Correlation Matrix of Low income countries

\begin{tabular}{|c|c|c|c|c|c|c|c|c|c|c|c|c|c|}
\hline & InFDI & trade & Mobile & InGDPp & Un & Inflation & Agriculture & $C C$ & GE & PS & $\mathrm{RQ}$ & $\mathrm{RL}$ & VA \\
\hline InFDI & 1.000 & & & & & & & & & & & & \\
\hline Trade & 0.335 & 1.000 & & & & & & & & & & & \\
\hline Mobile & 0.421 & 0.193 & 1.000 & & & & & & & & & & \\
\hline InGDPp & 0.326 & 0.069 & 0.388 & 1.000 & & & & & & & & & \\
\hline Un & 0.257 & 0.204 & 0.023 & -0.011 & 1.000 & & & & & & & & \\
\hline Inflation & -0.003 & 0.035 & -0.030 & 0.049 & -0.001 & 1.000 & & & & & & & \\
\hline Agriculture & -0.333 & 0.041 & -0.213 & -0.440 & -0.163 & -0.061 & 1.000 & & & & & & \\
\hline CC & 0.074 & -0.078 & 0.070 & 0.211 & 0.105 & -0.082 & -0.355 & 1.000 & & & & & \\
\hline GE & 0.156 & -0.156 & -0.009 & 0.381 & 0.161 & -0.046 & -0.521 & 0.781 & 1.000 & & & & \\
\hline PS & 0.261 & 0.088 & 0.126 & 0.366 & 0.251 & -0.030 & -0.364 & 0.568 & 0.622 & 1.000 & & & \\
\hline $\mathrm{RQ}$ & 0.240 & -0.168 & 0.086 & 0.287 & 0.136 & -0.150 & -0.344 & 0.739 & 0.812 & 0.616 & 1.000 & & \\
\hline $\mathrm{RL}$ & 0.227 & -0.067 & 0.094 & 0.330 & 0.079 & -0.104 & -0.413 & 0.773 & 0.844 & 0.720 & 0.880 & 1.000 & \\
\hline VA & 0.216 & 0.091 & 0.184 & 0.280 & 0.217 & -0.096 & -0.250 & 0.547 & 0.612 & 0.745 & 0.649 & 0.757 & 1.000 \\
\hline \multicolumn{14}{|c|}{ Descriptive Statistics of Low income Countries } \\
\hline & Obs. & Mean & Std. Dev. & Min. & Max. & & & & & & & & \\
\hline InFDI & 420 & 18.017 & 2.358 & 4.605 & 22.625 & & & & & & & & \\
\hline Trade & 420 & 61.464 & 31.303 & 20.964 & 311.360 & & & & & & & & \\
\hline Mobile & 420 & 23.441 & 29.562 & 0.000 & 149.070 & & & & & & & & \\
\hline InGDPp & 420 & 6.197 & 0.399 & 4.811 & 7.206 & & & & & & & & \\
\hline Inflation & 420 & 75.360 & 1192.571 & -35.837 & 24.411 & & & & & & & & \\
\hline Agriculture & 420 & 36.512 & 12.986 & 10.094 & 93.977 & & & & & & & & \\
\hline Index & 420 & -0.520 & 0.547 & -0.436 & 0.754 & & & & & & & & \\
\hline
\end{tabular}

Table 4 Correlation Matrix of Lower middle income countries

\begin{tabular}{|c|c|c|c|c|c|c|c|c|c|c|c|c|}
\hline & InFDI & Trade & Mobile & InGDPp & Inflation & Agriculture & CC & GE & PS & $\mathrm{RQ}$ & $\mathrm{RL}$ & VA \\
\hline InFDI & 1.000 & & & & & & & & & & & \\
\hline Trade & -0.186 & 1.000 & & & & & & & & & & \\
\hline Mobile & 0.438 & 0.178 & 1.000 & & & & & & & & & \\
\hline InGDPp & 0.175 & 0.300 & 0.489 & 1.000 & & & & & & & & \\
\hline Inflation & -0.048 & -0.130 & -0.173 & -0.284 & 1.000 & & & & & & & \\
\hline Agriculture & -0.212 & -0.347 & -0.388 & -0.661 & 0.378 & 1.000 & & & & & & \\
\hline CC & -0.299 & 0.335 & 0.079 & 0.431 & -0.204 & -0.322 & 1.000 & & & & & \\
\hline GE & -0.023 & 0.177 & 0.129 & 0.351 & -0.185 & -0.296 & 0.727 & 1.000 & & & & \\
\hline PS & -0.367 & 0.448 & -0.013 & 0.256 & -0.150 & -0.086 & 0.574 & 0.445 & 1.000 & & & \\
\hline $\mathrm{RQ}$ & 0.107 & 0.272 & 0.237 & 0.417 & -0.212 & -0.416 & 0.449 & 0.709 & 0.287 & 1.000 & & \\
\hline $\mathrm{RL}$ & -0.131 & 0.268 & 0.066 & 0.395 & -0.200 & -0.322 & 0.859 & 0.746 & 0.545 & 0.549 & 1.000 & \\
\hline VA & -0.031 & 0.194 & 0.105 & 0.245 & -0.149 & -0.239 & 0.507 & 0.448 & 0.441 & 0.473 & 0.602 & 1.000 \\
\hline \multicolumn{13}{|c|}{ Descriptive Statistics of Lower Middle Income Countries } \\
\hline & Obs. & Mean & Std. Dev. & Min. & Max. & & & & & & & \\
\hline InFDI & 819 & 19.536 & 1.946 & 11.795 & 24.518 & & & & & & & \\
\hline Trade & 819 & 81.252 & 64.355 & 0.167 & 170.407 & & & & & & & \\
\hline Mobile & 819 & 42.225 & 44.130 & 0.000 & 196.311 & & & & & & & \\
\hline $\operatorname{lnGDPp}$ & 819 & 7.393 & 0.545 & 5.556 & 8.358 & & & & & & & \\
\hline Inflation & 819 & 8.328 & 10.416 & -18.110 & 132.824 & & & & & & & \\
\hline Agriculture & 819 & 19.870 & 11.134 & 2.273 & 57.239 & & & & & & & \\
\hline Index & 819 & -0.455 & 0.761 & -2.351 & 1.918 & & & & & & & \\
\hline
\end{tabular}




\section{Appendix 2}

Table 5 Correlation Matrix of Upper middle income countries

\begin{tabular}{|c|c|c|c|c|c|c|c|c|c|c|c|c|}
\hline & InFDI & Trade & Mobile & InGDPp & Inflation & Agriculture & CC & GE & PS & $\mathrm{RQ}$ & $\mathrm{RL}$ & VA \\
\hline InFDI & 1.000 & & & & & & & & & & & \\
\hline trade & -0.261 & 1.000 & & & & & & & & & & \\
\hline Mobile & 0.353 & -0.062 & 1.000 & & & & & & & & & \\
\hline InGDPp & 0.401 & -0.090 & 0.498 & 1.000 & & & & & & & & \\
\hline inflation & -0.022 & -0.042 & -0.118 & -0.072 & 1.000 & & & & & & & \\
\hline Agriculture & -0.394 & 0.076 & -0.305 & -0.636 & 0.095 & 1.000 & & & & & & \\
\hline CC & -0.108 & 0.022 & 0.075 & 0.186 & -0.083 & -0.142 & 1.000 & & & & & \\
\hline GE & 0.135 & 0.008 & 0.211 & 0.311 & -0.096 & -0.156 & 0.812 & 1.000 & & & & \\
\hline PS & -0.322 & 0.225 & 0.030 & 0.134 & -0.048 & -0.080 & 0.550 & 0.431 & 1.000 & & & \\
\hline RQ & 0.179 & -0.016 & 0.159 & 0.306 & -0.145 & -0.160 & 0.703 & 0.825 & 0.340 & 1.000 & & \\
\hline RL & -0.208 & 0.069 & 0.077 & 0.205 & -0.113 & -0.073 & 0.857 & 0.821 & 0.656 & 0.747 & 1.000 & \\
\hline VA & -0.222 & -0.015 & 0.047 & 0.139 & -0.086 & 0.030 & 0.742 & 0.672 & 0.504 & 0.730 & 0.775 & 1.000 \\
\hline \multicolumn{13}{|c|}{ Descriptive Statistics of Upper Middle Income Countries } \\
\hline & Obs. & Mean & Std. Dev. & Min. & Max. & & & & & & & \\
\hline InFDI & 924 & 20.438 & 2.448 & 6.908 & 26.396 & & & & & & & \\
\hline Trade & 924 & 86.638 & 46.561 & 0.027 & 531.737 & & & & & & & \\
\hline Mobile & 924 & 58.694 & 49.111 & 0.000 & 185.822 & & & & & & & \\
\hline InGDPp & 924 & 8.592 & 0.473 & 7.106 & 9.920 & & & & & & & \\
\hline Inflation & 924 & 11.108 & 39.948 & -16.117 & 1058.374 & & & & & & & \\
\hline Agriculture & 924 & 9.769 & 6.367 & 0.892 & 41.491 & & & & & & & \\
\hline Index & 924 & -0.472 & 1.152 & -3.894 & 2.277 & & & & & & & \\
\hline
\end{tabular}

Table 6 Correlation Matrix of High income countries

\begin{tabular}{|c|c|c|c|c|c|c|c|c|c|c|c|c|}
\hline & InFDI & Trade & Mobile & InGDPp & Inflation & Agriculture & $\mathrm{CC}$ & GE & PS & $\mathrm{RQ}$ & $\mathrm{RL}$ & VA \\
\hline InFDI & 1.000 & & & & & & & & & & & \\
\hline Trade & 0.106 & 1.000 & & & & & & & & & & \\
\hline Mobile & 0.293 & 0.274 & 1.000 & & & & & & & & & \\
\hline InGDPp & 0.394 & 0.115 & 0.249 & 1.000 & & & & & & & & \\
\hline Inflation & -0.194 & -0.068 & -0.180 & -0.380 & 1.000 & & & & & & & \\
\hline Agriculture & -0.343 & -0.303 & -0.287 & -0.514 & 0.393 & 1.000 & & & & & & \\
\hline CC & 0.373 & 0.121 & 0.034 & 0.619 & -0.192 & -0.109 & 1.000 & & & & & \\
\hline GE & 0.453 & 0.185 & 0.084 & 0.631 & -0.275 & -0.209 & 0.904 & 1.000 & & & & \\
\hline PS & -0.010 & 0.258 & -0.087 & 0.316 & -0.073 & 0.032 & 0.524 & 0.507 & 1.000 & & & \\
\hline $\mathrm{RQ}$ & 0.483 & 0.296 & 0.109 & 0.466 & -0.218 & -0.157 & 0.795 & 0.863 & 0.445 & 1.000 & & \\
\hline RL & 0.448 & 0.112 & 0.088 & 0.642 & -0.260 & -0.152 & 0.919 & 0.920 & 0.524 & 0.379 & 1.000 & \\
\hline VA & 0.269 & -0.114 & -0.034 & 0.176 & -0.034 & 0.169 & 0.569 & 0.606 & 0.379 & 0.586 & 0.662 & 1.000 \\
\hline \multicolumn{13}{|c|}{ Descriptive Statistics of High Income Countries } \\
\hline & Obs. & Mean & Std. Dev. & Min. & Max. & & & & & & & \\
\hline InFDI & 945 & 22.231 & 2.184 & 14.509 & 27.322 & & & & & & & \\
\hline Trade & 945 & 107.483 & 76.220 & 18.349 & 442.620 & & & & & & & \\
\hline Mobile & 945 & 86.838 & 46.890 & 0.533 & 235.612 & & & & & & & \\
\hline $\operatorname{lnGDPp}$ & 945 & 10.266 & 0.621 & 8.579 & 11.626 & & & & & & & \\
\hline Inflation & 945 & 2.775 & 3.224 & -4.863 & 28.342 & & & & & & & \\
\hline Agriculture & 945 & 2.625 & 2.140 & 0.035 & 12.876 & & & & & & & \\
\hline Index & 945 & 0.716 & 0.681 & -0.659 & 2.488 & & & & & & & \\
\hline
\end{tabular}




\section{Appendix 3}

Table 7 Description of the variables

\begin{tabular}{lll}
\hline Variables Description & Definition of Variables & Source \\
\hline Control of corruption & Control of Corruption captures perceptions of the extent to which public & WGI \\
& power is exercised for private gain, including both petty and grand forms & \\
& of corruption, as well as "capture" of the state by elites and private interests. \\
& Estimate gives the country's score on the aggregate indicator, in units of a \\
& standard normal distribution, i.e. ranging from approximately -2.5 to 2.5.
\end{tabular}

Political stability Political Stability and Absence of Violence/Terrorism measures perceptions of the likelihood of political instability and/or politically-motivated violence, including terrorism. Estimate gives the country's score on the aggregate indicator, in units of a standard normal distribution, i.e. ranging from approximately -2.5 to 2.5 .

Rule and Law

Rule of Law captures perceptions of the extent to which agents have confidence in and abide by the rules of society, and in particular the quality of contract enforcement, property rights, the police, and the courts, as well as the likelihood of crime and violence. Estimate gives the country's score on the aggregate indicator, in units of a standard normal distribution, i.e. ranging from approximately -2.5 to 2.5 .

Voice and accountability

Voice and Accountability captures perceptions of the extent to which a country's citizens are able to participate in selecting their government, as well as freedom of expression, freedom of association, and a free media. Estimate gives the country's score on the aggregate indicator, in units of a standard normal distribution, i.e. ranging from approximately -2.5 to 2.5 .

Regulatory quality Regulatory Quality captures perceptions of the ability of the government to formulate and implement sound policies and regulations that permit and promote private sector development. Estimate gives the country's score on the aggregate indicator, in units of a standard normal distribution, i.e. ranging from approximately -2.5 to 2.5 .

Government effectiveness

Government Effectiveness captures perceptions of the quality of public services, the quality of the civil service and the degree of its independence from political pressures, the quality of policy formulation and implementation, and the credibility of the government's commitment to such policies. Estimate gives the country's score on the aggregate indicator, in units of a standard normal distribution, i.e. ranging from approximately -2.5 to 2.5 .

Trade Openness GDP per capita

Trade is the sum of exports and imports of goods and services measured as a share of gross domestic product. Annual percentage growth rate of GDP per capita based on constant local currency. Aggregates are based on constant 2005 U.S. dollars. GDP per capita is gross domestic product divided by midyear population. GDP at purchaser's prices is the sum of gross value added by all resident producers in the economy plus any product taxes and minus any subsidies not included in the value of the products. It is calculated without making deductions for depreciation of fabricated assets or for depletion and degradation of natural resources.

Inflation (CPI)

Inflation as measured by the consumer price index reflects the annual percentage change in the cost to the average consumer of acquiring a basket of goods and services that may be fixed or changed at specified intervals, such as yearly. The Lapsers formula is generally used.

Mobile Phone

Mobile cellular and telephone subscriptions are subscriptions to a public mobile telephone service that provide access to the PSTN using cellular technology. The indicator includes (and is split into) the number of post-paid subscriptions, and the number of active prepaid accounts (i.e. that have been used during the last three months). The indicator applies to all mobile cellular subscriptions that offer voice communications. It excludes subscriptions via data cards or USB modems, subscriptions to public mobile data services, private trunked mobile radio, tele point, radio paging and telemetry services. 
Table 8 List of developing countries

\begin{tabular}{|c|c|c|c|c|c|}
\hline \multicolumn{2}{|c|}{ Low Income Countries } & \multicolumn{4}{|c|}{ Lower Middle income countries } \\
\hline 1 & Benin & 1 & Armenia & 21 & Mauritania \\
\hline 2 & Burkina Faso & 2 & Bangladesh & 22 & Moldova \\
\hline 3 & Burundi & 3 & Bhutan & 23 & Mongolia \\
\hline 4 & Central African Republic & 4 & Bolivia & 24 & Morocco \\
\hline 5 & Chad & 5 & Cabo Verde & 25 & Myanmar \\
\hline 6 & Congo, Dem. Rep. & 6 & Cambodia & 26 & Nicaragua \\
\hline 7 & Guinea-Bissau & 7 & Cameroon & 27 & Nigeria \\
\hline 8 & Liberia & 8 & Congo, Rep. & 28 & Pakistan \\
\hline 9 & Madagascar & 9 & Egypt, Arab Rep. & 29 & Philippines \\
\hline 10 & Malawi & 10 & El Salvador & 30 & Solomon Islands \\
\hline 11 & Mali & 11 & Georgia & 31 & Sri Lanka \\
\hline 12 & Mozambique & 12 & Ghana & 32 & Sudan \\
\hline 13 & Nepal & 13 & Guatemala & 33 & Swaziland \\
\hline 14 & Rwanda & 14 & Honduras & 34 & Tunisia \\
\hline 15 & Senegal & 15 & India & 35 & Ukraine \\
\hline 16 & Sierra Leone & 16 & Jordan & 36 & Vanuatu \\
\hline 17 & Tanzania & 17 & Kenya & 37 & West Bank and Gaza \\
\hline 18 & Togo & 18 & Kyrgyz Republic & 38 & Yemen, Rep. \\
\hline 19 & Uganda & 19 & Lao PDR & 39 & Zambia \\
\hline 20 & Zimbabwe & 20 & Lesotho & & \\
\hline
\end{tabular}

Table 9 List of developed countries

\begin{tabular}{|c|c|c|c|c|c|c|c|}
\hline \multicolumn{4}{|c|}{ High Income Countries } & \multicolumn{4}{|c|}{ Upper Middle Income Countries } \\
\hline 1 & Australia & 24 & Kuwait & 1 & Albania & 23 & Jamaica \\
\hline 2 & Austria & 25 & Latvia & 2 & Belize & 24 & Kazakhstan \\
\hline 3 & Bahamas, The & 26 & Lithuania & 3 & Bulgaria & 25 & Macedonia, FYR \\
\hline 4 & Barbados & 27 & Luxembourg & 4 & Colombia & 26 & Malaysia \\
\hline 5 & Belgium & 28 & Malta & 5 & Iran, Islamic Rep. & 27 & Mauritius \\
\hline 6 & Brunei Darussalam & 29 & Netherlands & 6 & Algeria & 28 & Mexico \\
\hline 7 & Canada & 30 & New Zealand & 7 & Argentina & 29 & Namibia \\
\hline 8 & Chile & 31 & Norway & 8 & Azerbaijan & 30 & Panama \\
\hline 9 & Cyprus & 32 & Poland & 9 & Belarus & 31 & Paraguay \\
\hline 10 & Czech Republic & 33 & Portugal & 10 & Bosnia and Herzegovina & 32 & Peru \\
\hline 11 & Denmark & 34 & Qatar & 11 & Botswana & 33 & Romania \\
\hline 12 & Estonia & 35 & Saudi Arabia & 12 & Brazil & 34 & Russian Federation \\
\hline 13 & Finland & 36 & Singapore & 13 & China & 35 & Samoa \\
\hline 14 & France & 37 & Slovak Republic & 14 & Costa Rica & 36 & Serbia \\
\hline 15 & Germany & 38 & Slovenia & 15 & Croatia & 37 & South Africa \\
\hline 16 & Greece & 39 & Spain & 16 & Dominican Republic & 38 & St. Lucia \\
\hline 17 & Hong Kong SAR, China & 40 & Sweden & 17 & Ecuador & 39 & St. Vincent and the Grenadines \\
\hline 18 & Hungary & 41 & Switzerland & 18 & Equatorial Guinea & 40 & Suriname \\
\hline 19 & Iceland & 42 & Trinidad and Tobago & 19 & Fiji & 41 & Thailand \\
\hline 20 & Ireland & 43 & United Kingdom & 20 & Gabon & 42 & Tonga \\
\hline 21 & Israel & 44 & United States & 21 & Guyana & 43 & Turkey \\
\hline 22 & Italy & 45 & Uruguay & 22 & Iraq & 44 & Turkmenistan \\
\hline 23 & Korea, Rep. & & & & & & \\
\hline
\end{tabular}


Table 10 Control of corruption and FDI

\begin{tabular}{|c|c|c|c|c|c|c|c|c|}
\hline \multirow[t]{2}{*}{ Variables } & \multicolumn{2}{|c|}{$\begin{array}{l}\text { Low Income } \\
\text { Countries }\end{array}$} & \multicolumn{2}{|c|}{$\begin{array}{l}\text { Lower Middle } \\
\text { income Countries }\end{array}$} & \multicolumn{2}{|c|}{$\begin{array}{l}\text { High Income } \\
\text { Countries }\end{array}$} & \multicolumn{2}{|c|}{$\begin{array}{l}\text { Upper middle } \\
\text { income countries }\end{array}$} \\
\hline & FEM & GMM & FEM & GMM & FEM & GMM & FEM & GMM \\
\hline$(\mid n F D)_{t-1}$ & & $\begin{array}{l}0.479^{a} \\
(0.000)\end{array}$ & & $\begin{array}{l}0.619^{a} \\
(0.000)\end{array}$ & & $\begin{array}{l}0.313^{\mathrm{a}} \\
(0.000)\end{array}$ & & $\begin{array}{l}0.604^{a} \\
(0.001)\end{array}$ \\
\hline Trade & $\begin{array}{l}0.010 \\
(0.850)\end{array}$ & $\begin{array}{l}0.050^{\mathrm{a}} \\
(0.002)\end{array}$ & $\begin{array}{l}0.075^{\mathrm{a}} \\
(0.000)\end{array}$ & $\begin{array}{l}0.023^{\mathrm{a}} \\
(0.000)\end{array}$ & $\begin{array}{l}0.134^{\mathrm{a}} \\
(0.000)\end{array}$ & $\begin{array}{l}0.019^{\mathrm{a}} \\
(0.000)\end{array}$ & $\begin{array}{l}0.037 \\
(0.403)\end{array}$ & $\begin{array}{l}0.047^{\mathrm{a}} \\
(0.010)\end{array}$ \\
\hline InMobile & $\begin{array}{l}-0.437 \\
(0.217)\end{array}$ & $\begin{array}{l}0.364^{c} \\
(0.075)\end{array}$ & $\begin{array}{l}0.069 \\
(0.511)\end{array}$ & $\begin{array}{l}0.092 \\
(0.279)\end{array}$ & $\begin{array}{l}0.815^{\mathrm{a}} \\
(0.000)\end{array}$ & $\begin{array}{l}0.037 \\
(0.761)\end{array}$ & $\begin{array}{l}3.151^{\mathrm{b}} \\
(0.014)\end{array}$ & $\begin{array}{l}-0.051 \\
(0.899)\end{array}$ \\
\hline $\begin{array}{l}\text { LnGDP per } \\
\text { capita }\end{array}$ & $\begin{array}{l}12.734 \\
(0.217)\end{array}$ & $\begin{array}{l}14.232^{b} \\
(0.032)\end{array}$ & $\begin{array}{l}-0.634 \\
(0.599)\end{array}$ & $\begin{array}{l}12.563^{\mathrm{a}} \\
(0.002)\end{array}$ & $\begin{array}{l}-8.873 \\
(0.120)\end{array}$ & $\begin{array}{l}3.445 \\
(0.110)\end{array}$ & $\begin{array}{l}9.145 \\
(0.289)\end{array}$ & $\begin{array}{l}4.606 \\
(0.233)\end{array}$ \\
\hline Inflation & $\begin{array}{l}0.0001^{c} \\
(0.065)\end{array}$ & $\begin{array}{l}0.0001 \\
(0.920)\end{array}$ & $\begin{array}{l}0.017 \\
(0.341)\end{array}$ & $\begin{array}{l}-0.060^{b} \\
(0.017)\end{array}$ & $\begin{array}{l}0.000 \\
(0.954)\end{array}$ & $\begin{array}{l}-0.032 \\
(0.115)\end{array}$ & $\begin{array}{l}0.350 \\
(0.244)\end{array}$ & $\begin{array}{l}-0.298^{c} \\
(0.065)\end{array}$ \\
\hline $\begin{array}{l}\text { Agriculture } \\
\text { value added }\end{array}$ & $\begin{array}{l}-0.506^{\mathrm{b}} \\
(0.015)\end{array}$ & $\begin{array}{l}0.046 \\
(0.242)\end{array}$ & $\begin{array}{l}-0.096^{b} \\
(0.042)\end{array}$ & $\begin{array}{l}-0.021 \\
(0.406)\end{array}$ & $\begin{array}{l}-0.166 \\
(0.179)\end{array}$ & $\begin{array}{l}-0.086 \\
(0.157)\end{array}$ & $\begin{array}{l}0.017 \\
(0.990)\end{array}$ & $\begin{array}{l}0.128 \\
(0.560)\end{array}$ \\
\hline $\begin{array}{l}\text { Control over } \\
\text { Corruption }\end{array}$ & $\begin{array}{l}3.584 \\
(0.293)\end{array}$ & $\begin{array}{l}0.011^{c} \\
(0.083)\end{array}$ & $\begin{array}{l}0.471 \\
(0.537)\end{array}$ & $\begin{array}{l}0.076^{c} \\
(0.096)\end{array}$ & $\begin{array}{l}0.439 \\
(0.629)\end{array}$ & $\begin{array}{l}5.611^{b} \\
(0.017)\end{array}$ & $\begin{array}{l}2.295^{b} \\
(0.013)\end{array}$ & $\begin{array}{l}4.438^{c} \\
(0.103)\end{array}$ \\
\hline Constant & $\begin{array}{l}58.560 \\
(0.291)\end{array}$ & $\begin{array}{l}18.653^{\mathrm{b}} \\
(0.038)\end{array}$ & $\begin{array}{l}4.058 \\
(0.669)\end{array}$ & $\begin{array}{l}2.407^{c} \\
(0.105)\end{array}$ & $\begin{array}{l}8.574^{a} \\
(0.000)\end{array}$ & $\begin{array}{l}13.125^{c} \\
(0.081)\end{array}$ & $\begin{array}{l}7.295 \\
(0.408)\end{array}$ & $\begin{array}{l}9.540^{\mathrm{b}} \\
(0.046)\end{array}$ \\
\hline$A R(1)$ & & 0.000 & & 0.000 & 0.385 & 0.000 & & 0.040 \\
\hline$A R(2)$ & & 0.635 & & 0.341 & & 0.359 & & 0.215 \\
\hline Sargan & & 0.102 & & 0.428 & & 0.175 & & 0.13 \\
\hline
\end{tabular}

Note: ${ }^{\mathrm{a}}{ }^{\mathrm{b}}$ and ${ }^{\mathrm{c}}$ denote significance at $1 \%, 5 \%$ and $10 \%$ level respectively. Parenthesis show $P$-values

Table 11 Government effectiveness and FDI

\begin{tabular}{|c|c|c|c|c|c|c|c|c|}
\hline \multirow[t]{2}{*}{ Variables } & \multicolumn{2}{|c|}{$\begin{array}{l}\text { Low Income } \\
\text { Countries }\end{array}$} & \multicolumn{2}{|c|}{$\begin{array}{l}\text { Lower Middle } \\
\text { Income Countries }\end{array}$} & \multicolumn{2}{|c|}{$\begin{array}{l}\text { High Income } \\
\text { Countries }\end{array}$} & \multicolumn{2}{|c|}{$\begin{array}{l}\text { Upper Middle } \\
\text { Income Countries }\end{array}$} \\
\hline & FEM & GMM & FEM & GMM & FEM & GMM & FEM & GMM \\
\hline$(I n F D)_{t-1}$ & & $\begin{array}{l}0.250^{a} \\
(0.000)\end{array}$ & & $\begin{array}{l}0.645^{a} \\
(0.000)\end{array}$ & & $\begin{array}{l}0.305^{\mathrm{a}} \\
(0.000)\end{array}$ & & $\begin{array}{l}0.605^{a} \\
(0.001)\end{array}$ \\
\hline Trade & $\begin{array}{l}0.007 \\
(0.891)\end{array}$ & $\begin{array}{l}0.083^{\mathrm{a}} \\
(0.000)\end{array}$ & $\begin{array}{l}0.073^{\mathrm{a}} \\
(0.000)\end{array}$ & $\begin{array}{l}0.131^{\mathrm{a}} \\
(0.000)\end{array}$ & $\begin{array}{l}0.019^{a} \\
(0.000)\end{array}$ & $\begin{array}{l}0.020^{\mathrm{a}} \\
(0.000)\end{array}$ & $\begin{array}{l}0.040 \\
(0.362)\end{array}$ & $\begin{array}{l}0.048^{\mathrm{a}} \\
(0.007)\end{array}$ \\
\hline InMobile & $\begin{array}{l}-0.406 \\
(0.214)\end{array}$ & $\begin{array}{l}0.498^{b} \\
(0.015)\end{array}$ & $\begin{array}{l}0.120 \\
(0.255)\end{array}$ & $\begin{array}{l}0.820^{\mathrm{a}} \\
(0.000)\end{array}$ & $\begin{array}{l}0.066 \\
(0.409)\end{array}$ & $\begin{array}{l}0.027 \\
(0.816)\end{array}$ & $\begin{array}{l}2.875^{\mathrm{b}} \\
(0.026)\end{array}$ & $\begin{array}{l}-0.192 \\
(0.562)\end{array}$ \\
\hline LnGDP per capita & $\begin{array}{l}11.889 \\
(0.212)\end{array}$ & $\begin{array}{l}25.597^{\mathrm{a}} \\
(0.001)\end{array}$ & $\begin{array}{l}-1.333 \\
(0.270)\end{array}$ & $\begin{array}{l}-9.318^{a} \\
(0.000)\end{array}$ & $\begin{array}{l}4.311 \\
(0.348)\end{array}$ & $\begin{array}{l}4.228 \\
(0.120)\end{array}$ & $\begin{array}{l}6.774 \\
(0.456)\end{array}$ & $\begin{array}{l}7.261 \\
(0.309)\end{array}$ \\
\hline Inflation & $\begin{array}{l}0.0001^{c} \\
(0.067)\end{array}$ & $\begin{array}{l}0.000 \\
(0.850)\end{array}$ & $\begin{array}{l}0.017 \\
(0.331)\end{array}$ & $\begin{array}{l}-0.005 \\
(0.911)\end{array}$ & $\begin{array}{l}-0.014 \\
(0.439)\end{array}$ & $\begin{array}{l}-0.023 \\
(0.167)\end{array}$ & $\begin{array}{l}0.369 \\
(0.221)\end{array}$ & $\begin{array}{l}0.211^{c} \\
(0.091)\end{array}$ \\
\hline $\begin{array}{l}\text { Agriculture } \\
\text { value added }\end{array}$ & $\begin{array}{l}0.490^{\mathrm{a}} \\
(0.007)\end{array}$ & $\begin{array}{l}0.111^{b} \\
(0.013)\end{array}$ & $\begin{array}{l}0.106^{b} \\
(0.025)\end{array}$ & $\begin{array}{l}0.155^{\mathrm{C}} \\
(0.097)\end{array}$ & $\begin{array}{l}0.004 \\
(0.898)\end{array}$ & $\begin{array}{l}-0.120 \\
(0.106)\end{array}$ & $\begin{array}{l}0.254 \\
(0.849)\end{array}$ & $\begin{array}{l}0.268 \\
(0.155)\end{array}$ \\
\hline $\begin{array}{l}\text { Government } \\
\text { effectiveness }\end{array}$ & $\begin{array}{l}-2.216 \\
(0.566)\end{array}$ & $\begin{array}{l}0.110^{\mathrm{b}} \\
(0.022)\end{array}$ & $\begin{array}{l}1.263 \\
(0.110)\end{array}$ & $\begin{array}{l}0.155^{b} \\
(0.044)\end{array}$ & $\begin{array}{l}-0.737^{c} \\
(0.105)\end{array}$ & $\begin{array}{l}1.182^{c} \\
(0.065)\end{array}$ & $\begin{array}{l}0.046 \\
(0.992)\end{array}$ & $\begin{array}{l}6.371^{\mathrm{b}} \\
(0.012)\end{array}$ \\
\hline Constant & $\begin{array}{l}53.075 \\
(0.357)\end{array}$ & $\begin{array}{l}35.489^{\mathrm{a}} \\
(0.001)\end{array}$ & $\begin{array}{l}10.454 \\
(0.280)\end{array}$ & $\begin{array}{l}7.680^{\mathrm{a}} \\
(0.000)\end{array}$ & $\begin{array}{l}0.870 \\
(0.850)\end{array}$ & $\begin{array}{l}19.750^{\mathrm{a}} \\
(0.008)\end{array}$ & $\begin{array}{l}9.583 \\
(0.501)\end{array}$ & $\begin{array}{l}4.752^{b} \\
(0.035)\end{array}$ \\
\hline$A R(1)$ & & 0.000 & & 0.000 & & 0.000 & & 0.055 \\
\hline $\operatorname{AR}(2)$ & & 0.176 & & 0.118 & & 0.216 & & 0.212 \\
\hline Sargan & & 0.334 & & 0.664 & & 0.385 & & 0.326 \\
\hline
\end{tabular}


Table 12 Political stability and FDI

\begin{tabular}{|c|c|c|c|c|c|c|c|c|}
\hline \multirow[t]{2}{*}{ Variables } & \multicolumn{2}{|c|}{$\begin{array}{l}\text { Low Income } \\
\text { Countries }\end{array}$} & \multicolumn{2}{|c|}{$\begin{array}{l}\text { Lower Middle } \\
\text { income Countries }\end{array}$} & \multicolumn{2}{|c|}{$\begin{array}{l}\text { High income } \\
\text { countries }\end{array}$} & \multicolumn{2}{|c|}{$\begin{array}{l}\text { Upper Middle } \\
\text { Income Countries }\end{array}$} \\
\hline & FEM & GMM & FEM & GMM & FEM & GMM & FEM & GMM \\
\hline$(\mid n F D)_{t-1}$ & & $\begin{array}{l}0.257^{a} \\
(0.000)\end{array}$ & & $\begin{array}{l}0.634^{a} \\
(0.000)\end{array}$ & & $\begin{array}{l}0.361^{a} \\
(0.000)\end{array}$ & & $\begin{array}{l}0.594^{a} \\
(0.003)\end{array}$ \\
\hline trade & $\begin{array}{l}0.007^{\mathrm{a}} \\
(0.004)\end{array}$ & $\begin{array}{l}0.080^{\mathrm{a}} \\
(0.000)\end{array}$ & $\begin{array}{l}0.072^{\mathrm{a}} \\
(0.000)\end{array}$ & $\begin{array}{l}0.023^{\mathrm{a}} \\
(0.000)\end{array}$ & $\begin{array}{l}0.134^{\mathrm{a}} \\
(0.000)\end{array}$ & $\begin{array}{l}0.011^{\mathrm{b}} \\
(0.020)\end{array}$ & $\begin{array}{l}0.040 \\
(0.364)\end{array}$ & $\begin{array}{l}0.044^{b} \\
(0.038)\end{array}$ \\
\hline InMobile & $\begin{array}{l}0.356^{\mathrm{b}} \\
(0.023)\end{array}$ & $\begin{array}{l}0.420^{\mathrm{b}} \\
(0.036)\end{array}$ & $\begin{array}{l}0.135 \\
(0.227)\end{array}$ & $\begin{array}{l}0.012 \\
(0.893)\end{array}$ & $\begin{array}{l}0.816^{\mathrm{a}} \\
(0.000)\end{array}$ & $\begin{array}{l}0.053 \\
(0.649)\end{array}$ & $\begin{array}{l}2.866^{b} \\
(0.028)\end{array}$ & $\begin{array}{l}0.003 \\
(0.992)\end{array}$ \\
\hline $\begin{array}{l}\text { LnGDP per } \\
\text { capita }\end{array}$ & $\begin{array}{l}11.900^{\mathrm{a}} \\
(0.002)\end{array}$ & $\begin{array}{l}8.534^{\mathrm{a}} \\
(0.000)\end{array}$ & $\begin{array}{l}-1.252 \\
(0.303)\end{array}$ & $\begin{array}{l}2.343^{\mathrm{a}} \\
(0.010)\end{array}$ & $\begin{array}{l}-8.908^{\mathrm{a}} \\
(0.000)\end{array}$ & $\begin{array}{l}3.623^{\mathrm{a}} \\
(0.000)\end{array}$ & $\begin{array}{l}6.739 \\
(0.438)\end{array}$ & $\begin{array}{l}2.890^{c} \\
(0.105)\end{array}$ \\
\hline inflation & $\begin{array}{l}0.0001^{c} \\
(0.084)\end{array}$ & $\begin{array}{l}-0.001 \\
(0.971)\end{array}$ & $\begin{array}{l}0.021 \\
(0.252)\end{array}$ & $\begin{array}{l}-0.015 \\
(0.396)\end{array}$ & $\begin{array}{l}-0.002 \\
(0.963)\end{array}$ & $\begin{array}{l}-0.037^{c} \\
(0.051)\end{array}$ & $\begin{array}{l}0.368 \\
(0.229)\end{array}$ & $\begin{array}{l}-0.216^{c} \\
(0.104)\end{array}$ \\
\hline agriculture & $\begin{array}{l}-0.499^{b} \\
(0.013)\end{array}$ & $\begin{array}{l}0.102^{c} \\
(0.014)\end{array}$ & $\begin{array}{l}-0.099^{b} \\
(0.034)\end{array}$ & $\begin{array}{l}0.009^{c} \\
(0.100)\end{array}$ & $\begin{array}{l}-0.171^{c} \\
(0.068)\end{array}$ & $\begin{array}{l}-0.052 \\
(0.229)\end{array}$ & $\begin{array}{l}0.262 \\
(0.844)\end{array}$ & $\begin{array}{l}0.028 \\
(0.916)\end{array}$ \\
\hline Political stability & $\begin{array}{l}1.281^{\mathrm{b}} \\
(0.038)\end{array}$ & $\begin{array}{l}3.390^{c} \\
(0.081)\end{array}$ & $\begin{array}{l}0.563 \\
(0.212)\end{array}$ & $\begin{array}{l}1.798^{b} \\
(0.042)\end{array}$ & $\begin{array}{l}0.197 \\
(0.745)\end{array}$ & $\begin{array}{l}4.025^{\mathrm{a}} \\
(0.000)\end{array}$ & $\begin{array}{l}0.190 \\
(0.960)\end{array}$ & $\begin{array}{l}2.668^{c} \\
(0.076)\end{array}$ \\
\hline Constant & $\begin{array}{l}51.835 \\
(0.307)\end{array}$ & $\begin{array}{l}32.388^{\mathrm{a}} \\
(0.002)\end{array}$ & $\begin{array}{l}9.363 \\
(0.322)\end{array}$ & $\begin{array}{l}0.305^{b} \\
(0.020)\end{array}$ & $\begin{array}{l}8.770^{c} \\
(0.000)\end{array}$ & $\begin{array}{l}9.519^{b} \\
(0.018)\end{array}$ & $\begin{array}{l}9.354 \\
(0.488)\end{array}$ & $\begin{array}{l}12.316^{b} \\
(0.040)\end{array}$ \\
\hline$A R(1)$ & & 0.000 & & 0.000 & 0.385 & 0.000 & & 0.002 \\
\hline $\operatorname{AR}(2)$ & & 0.118 & & 0.128 & & 0.197 & & 0.220 \\
\hline Sargan & & 442.000 & & 0.301 & & 0.167 & & 0.116 \\
\hline
\end{tabular}

Note: ${ }^{\mathrm{a}}{ }^{\mathrm{b}}$ and ${ }^{\mathrm{c}}$ denote significance at $1 \%, 5 \%$ and $10 \%$ level respectively. Parenthesis show $P$-values

Table 13 Regulatory Quality and FDI

\begin{tabular}{|c|c|c|c|c|c|c|c|c|}
\hline \multirow[t]{2}{*}{$\begin{array}{l}\text { Variables } \\
\text { nat }\end{array}$} & \multicolumn{2}{|c|}{$\begin{array}{l}\text { Low Income } \\
\text { Countries }\end{array}$} & \multicolumn{2}{|c|}{$\begin{array}{l}\text { Lower Middle } \\
\text { income Countries }\end{array}$} & \multicolumn{2}{|c|}{$\begin{array}{l}\text { High Income } \\
\text { Countries }\end{array}$} & \multicolumn{2}{|c|}{$\begin{array}{l}\text { Upper Middle } \\
\text { income Countries }\end{array}$} \\
\hline & $\overline{F E M}$ & $\overline{G M M}$ & $\overline{\mathrm{FEM}}$ & GMM & $\overline{F E M}$ & $\overline{\text { GMM }}$ & $\overline{F E M}$ & GMM \\
\hline$(\operatorname{lnFDI})_{t-1}$ & & $\begin{array}{l}0.576^{\mathrm{a}} \\
(0.000)\end{array}$ & & $\begin{array}{l}0.638^{\mathrm{a}} \\
(0.000)\end{array}$ & & $\begin{array}{l}0.331^{\mathrm{a}} \\
(0.000)\end{array}$ & & $\begin{array}{l}0.623^{\mathrm{a}} \\
(0.000)\end{array}$ \\
\hline Trade & $\begin{array}{l}0.007^{\mathrm{a}} \\
(0.001)\end{array}$ & $\begin{array}{l}0.035^{\mathrm{b}} \\
(0.029)\end{array}$ & $\begin{array}{l}0.072^{\mathrm{a}} \\
(0.000)\end{array}$ & $\begin{array}{l}0.020^{\mathrm{a}} \\
(0.000)\end{array}$ & $\begin{array}{l}0.133^{\mathrm{a}} \\
(0.000)\end{array}$ & $\begin{array}{l}0.017^{\mathrm{a}} \\
(0.000)\end{array}$ & $\begin{array}{l}0.041 \\
(0.358)\end{array}$ & $\begin{array}{l}0.049^{\mathrm{a}} \\
(0.003)\end{array}$ \\
\hline InMobile & $\begin{array}{l}-0.368^{b} \\
(0.032)\end{array}$ & $\begin{array}{l}0.326 \\
(0.120)\end{array}$ & $\begin{array}{l}0.123 \\
(0.237)\end{array}$ & $\begin{array}{l}0.023 \\
(0.774)\end{array}$ & $\begin{array}{l}0.875^{\mathrm{a}} \\
(0.000)\end{array}$ & $\begin{array}{l}0.196^{c} \\
(0.109)\end{array}$ & $\begin{array}{l}2.905^{b} \\
(0.027)\end{array}$ & $\begin{array}{l}0.455^{c} \\
(0.107)\end{array}$ \\
\hline LnGDP per capita & $\begin{array}{l}11.794^{\mathrm{b}} \\
(0.023)\end{array}$ & $\begin{array}{l}3.399^{\mathrm{a}} \\
(0.000)\end{array}$ & $\begin{array}{l}-1.307 \\
(0.269)\end{array}$ & $\begin{array}{l}7.374^{\mathrm{a}} \\
(0.000)\end{array}$ & $\begin{array}{l}-9.379 \\
(0.650)\end{array}$ & $\begin{array}{l}4.168 \\
(0.150)\end{array}$ & $\begin{array}{l}7.136 \\
(0.432)\end{array}$ & $\begin{array}{l}10.658 \\
(0.113)\end{array}$ \\
\hline Inflation & $\begin{array}{l}0.000^{\mathrm{b}} \\
(0.026)\end{array}$ & $\begin{array}{l}0.000 \\
(0.723)\end{array}$ & $\begin{array}{l}0.018 \\
(0.304)\end{array}$ & $\begin{array}{l}-0.015 \\
(0.383)\end{array}$ & $\begin{array}{l}0.006 \\
(0.898)\end{array}$ & $\begin{array}{l}-0.033 \\
(0.088)\end{array}$ & $\begin{array}{l}0.367 \\
(0.224)\end{array}$ & $\begin{array}{l}-0.215^{c} \\
(0.105)\end{array}$ \\
\hline $\begin{array}{l}\text { Agriculture } \\
\text { value added }\end{array}$ & $\begin{array}{l}-0.490^{\mathrm{b}} \\
(0.028)\end{array}$ & $\begin{array}{l}0.036 \\
(0.355)\end{array}$ & $\begin{array}{l}-0.093^{b} \\
(0.045)\end{array}$ & $\begin{array}{l}0.015 \\
(0.502)\end{array}$ & $\begin{array}{l}-0.137 \\
(0.149)\end{array}$ & $\begin{array}{l}-0.035 \\
(0.417)\end{array}$ & $\begin{array}{l}0.249 \\
(0.850)\end{array}$ & $\begin{array}{l}0.522^{\mathrm{b}} \\
(0.038)\end{array}$ \\
\hline Regulatory Quality & $\begin{array}{l}-1.727 \\
(0.654)\end{array}$ & $\begin{array}{l}5.859 \\
(0.188)\end{array}$ & $\begin{array}{l}1.517 \\
(0.219)\end{array}$ & $\begin{array}{l}0.195 \\
(0.114)\end{array}$ & $\begin{array}{l}1.575^{c} \\
(0.053)\end{array}$ & $\begin{array}{l}3.130^{\mathrm{a}} \\
(0.009)\end{array}$ & $\begin{array}{l}0.543 \\
(0.909)\end{array}$ & $\begin{array}{l}0.605^{c} \\
(0.064)\end{array}$ \\
\hline Constant & $\begin{array}{l}51.803^{b} \\
(0.036)\end{array}$ & $\begin{array}{l}15.552^{c} \\
(0.094)\end{array}$ & $\begin{array}{l}10.090 \\
(0.272)\end{array}$ & $\begin{array}{l}-2.127^{\mathrm{a}} \\
(0.000)\end{array}$ & $\begin{array}{l}7.613^{\mathrm{a}} \\
(0.000)\end{array}$ & $\begin{array}{l}2.833^{c} \\
(0.079)\end{array}$ & $\begin{array}{l}6.424 \\
(0.471)\end{array}$ & $\begin{array}{l}13.969^{\mathrm{b}} \\
(0.029)\end{array}$ \\
\hline$A R(1)$ & & 0.000 & & 0.000 & 0.387 & 0.000 & & 0.046 \\
\hline$A R(2)$ & & 0.335 & & 0.112 & & 0.194 & & 0.226 \\
\hline Sargan & & 0.256 & & 0.611 & & 0.367 & & 0.275 \\
\hline
\end{tabular}

Note: ${ }^{a},{ }^{b}$ and ${ }^{c}$ denote significance at $1 \%, 5 \%$ and $10 \%$ level respectively. Parenthesis show $P$-values 
Table 14 Rule of Law and FDI

\begin{tabular}{|c|c|c|c|c|c|c|c|c|}
\hline \multirow[t]{2}{*}{ Variables } & \multicolumn{2}{|c|}{$\begin{array}{l}\text { Low Income } \\
\text { Countries }\end{array}$} & \multicolumn{2}{|c|}{$\begin{array}{l}\text { Lower Middle } \\
\text { income Countries }\end{array}$} & \multicolumn{2}{|c|}{$\begin{array}{l}\text { High income } \\
\text { countries }\end{array}$} & \multicolumn{2}{|c|}{$\begin{array}{l}\text { Upper middle } \\
\text { income countries }\end{array}$} \\
\hline & $\overline{\text { FEM }}$ & GMM & $\overline{\mathrm{FEM}}$ & GMM & $\overline{\mathrm{FEM}}$ & GMM & $\overline{\mathrm{FEM}}$ & GMM \\
\hline$(\operatorname{lnFD})_{t-1}$ & & $\begin{array}{l}0.575^{\mathrm{a}} \\
(0.000)\end{array}$ & & $\begin{array}{l}0.657^{\mathrm{a}} \\
(0.000)\end{array}$ & & $\begin{array}{l}0.304^{\mathrm{a}} \\
(0.000)\end{array}$ & & $\begin{array}{l}0.607^{\mathrm{a}} \\
(0.000)\end{array}$ \\
\hline Trade & $\begin{array}{l}0.010^{\mathrm{a}} \\
(0.003)\end{array}$ & $\begin{array}{l}0.031^{c} \\
(0.052)\end{array}$ & $\begin{array}{l}0.073^{\mathrm{a}} \\
(0.000)\end{array}$ & $\begin{array}{l}0.018^{\mathrm{a}} \\
(0.002)\end{array}$ & $\begin{array}{l}0.133^{\mathrm{a}} \\
(0.000)\end{array}$ & $\begin{array}{l}0.017^{\mathrm{a}} \\
(0.001)\end{array}$ & $\begin{array}{l}0.027 \\
(0.534)\end{array}$ & $\begin{array}{l}0.045^{b} \\
(0.014)\end{array}$ \\
\hline InMobile & $\begin{array}{l}0.397^{b} \\
(0.022)\end{array}$ & $\begin{array}{l}0.338^{c} \\
(0.106)\end{array}$ & $\begin{array}{l}0.108 \\
(0.300)\end{array}$ & $\begin{array}{l}0.038 \\
(0.693)\end{array}$ & $\begin{array}{l}0.909^{\mathrm{a}} \\
(0.000)\end{array}$ & $\begin{array}{l}0.041 \\
(0.786)\end{array}$ & $\begin{array}{l}3.698^{\mathrm{a}} \\
(0.005)\end{array}$ & $\begin{array}{l}0.294 \\
(0.356)\end{array}$ \\
\hline LnGDP per capita & $\begin{array}{l}12.320^{\mathrm{b}} \\
(0.021)\end{array}$ & $\begin{array}{l}7.620^{\mathrm{a}} \\
(0.001)\end{array}$ & $\begin{array}{l}-1.170 \\
(0.326)\end{array}$ & $\begin{array}{l}3.384^{b} \\
(0.038)\end{array}$ & $\begin{array}{l}9.628^{a} \\
(0.000)\end{array}$ & $\begin{array}{l}3.319^{\mathrm{a}} \\
(0.000)\end{array}$ & $\begin{array}{l}7.257^{c} \\
(0.059)\end{array}$ & $\begin{array}{l}5.116^{\mathrm{b}} \\
(0.043)\end{array}$ \\
\hline Inflation & $\begin{array}{l}0.000^{c} \\
(0.063)\end{array}$ & $\begin{array}{l}0.000 \\
(0.787)\end{array}$ & $\begin{array}{l}-0.018 \\
(0.302)\end{array}$ & $\begin{array}{l}-0.014 \\
(0.425)\end{array}$ & $\begin{array}{l}0.000 \\
(0.930)\end{array}$ & $\begin{array}{l}-0.005 \\
(0.830)\end{array}$ & $\begin{array}{l}0.345 \\
(0.250)\end{array}$ & $\begin{array}{l}-0.095^{\mathrm{a}} \\
(0.003)\end{array}$ \\
\hline $\begin{array}{l}\text { Agriculture } \\
\text { value added }\end{array}$ & $\begin{array}{l}-0.498^{b} \\
(0.014)\end{array}$ & $\begin{array}{l}0.037 \\
(0.355)\end{array}$ & $\begin{array}{l}-0.101^{b} \\
(0.031)\end{array}$ & $\begin{array}{l}0.008 \\
(0.725)\end{array}$ & $\begin{array}{l}-0.149 \\
(0.112)\end{array}$ & $\begin{array}{l}-0.062 \\
(0.282)\end{array}$ & $\begin{array}{l}-0.145 \\
(0.912)\end{array}$ & $\begin{array}{l}0.067 \\
(0.872)\end{array}$ \\
\hline Rule of law & $\begin{array}{l}-2.368 \\
(0.508)\end{array}$ & $\begin{array}{l}5.171 \\
(0.172)\end{array}$ & $\begin{array}{l}1.132 \\
(0.147)\end{array}$ & $\begin{array}{l}6.451^{\mathrm{C}} \\
(0.105)\end{array}$ & $\begin{array}{l}2.685^{\mathrm{a}} \\
(0.007)\end{array}$ & $\begin{array}{l}3.893^{b} \\
(0.030)\end{array}$ & $\begin{array}{l}6.818^{a} \\
(0.001)\end{array}$ & $\begin{array}{l}4.719^{\mathrm{a}} \\
(0.002)\end{array}$ \\
\hline Constant & $\begin{array}{l}5.536 \\
(0.341)\end{array}$ & $\begin{array}{l}17.812^{c} \\
(0.055)\end{array}$ & $\begin{array}{l}9.084 \\
(0.329)\end{array}$ & $\begin{array}{l}2.075^{c} \\
(0.069)\end{array}$ & $\begin{array}{l}7.307^{\mathrm{a}} \\
(0.000)\end{array}$ & $\begin{array}{l}10.143^{b} \\
(0.034)\end{array}$ & $\begin{array}{l}14.791^{\mathrm{C}} \\
(0.100)\end{array}$ & $\begin{array}{l}18.301^{\mathrm{b}} \\
(0.042)\end{array}$ \\
\hline $\mathrm{AR}(1)$ & & 0.000 & & 0.000 & 0.390 & 0.000 & & 0.0450 \\
\hline $\mathrm{AR}(2)$ & & 0.394 & & 0.114 & & 0.481 & & 0.2240 \\
\hline Sargan & & 0.210 & & 0.382 & & 0.526 & & 0.1830 \\
\hline
\end{tabular}

Note: ${ }^{a}{ }^{b}$ and ${ }^{c}$ denote significance at $1 \%, 5 \%$ and $10 \%$ level respectively. Parenthesis show $P$-values

Table 15 Voice and Accountability and FDI

\begin{tabular}{|c|c|c|c|c|c|c|c|c|}
\hline \multirow[t]{2}{*}{ Variables } & \multicolumn{2}{|c|}{$\begin{array}{l}\text { Low Income } \\
\text { Countries }\end{array}$} & \multicolumn{2}{|c|}{$\begin{array}{l}\text { Lower Middle } \\
\text { income Countries }\end{array}$} & \multicolumn{2}{|c|}{$\begin{array}{l}\text { High Income } \\
\text { countries }\end{array}$} & \multicolumn{2}{|c|}{$\begin{array}{l}\text { Upper Middle } \\
\text { income countries }\end{array}$} \\
\hline & $\overline{\text { FEM }}$ & GMM & $\overline{\mathrm{FEM}}$ & GMM & $\overline{\text { FEM }}$ & GMM & $\overline{\text { FEM }}$ & GMM \\
\hline$(\operatorname{lnFDI})_{t-1}$ & & $\begin{array}{l}0.568^{\mathrm{a}} \\
(0.000)\end{array}$ & & $\begin{array}{l}0.682^{\mathrm{a}} \\
(0.000)\end{array}$ & & $\begin{array}{l}0.302^{\mathrm{a}} \\
(0.000)\end{array}$ & & $\begin{array}{l}0.606^{a} \\
(0.001)\end{array}$ \\
\hline Trade & $\begin{array}{l}0.010 \\
(0.200)\end{array}$ & $\begin{array}{l}0.310^{c} \\
(0.053)\end{array}$ & $\begin{array}{l}0.073^{\mathrm{a}} \\
(0.000)\end{array}$ & $\begin{array}{l}0.019^{a} \\
(0.003)\end{array}$ & $\begin{array}{l}0.134^{a} \\
(0.000)\end{array}$ & $\begin{array}{l}0.019^{a} \\
(0.000)\end{array}$ & $\begin{array}{l}0.360 \\
(0.411)\end{array}$ & $\begin{array}{l}0.051^{a} \\
(0.002)\end{array}$ \\
\hline InMobile & $\begin{array}{l}0.397 \\
(0.228)\end{array}$ & $\begin{array}{l}0.334^{c} \\
(0.107)\end{array}$ & $\begin{array}{l}0.044 \\
(0.669)\end{array}$ & $\begin{array}{l}0.130 \\
(0.212)\end{array}$ & $\begin{array}{l}0.813^{\mathrm{a}} \\
(0.000)\end{array}$ & $\begin{array}{l}0.154 \\
(0.318)\end{array}$ & $\begin{array}{l}3.176^{\mathrm{b}} \\
(0.015)\end{array}$ & $\begin{array}{l}0.492 \\
(0.135)\end{array}$ \\
\hline LnGDP per capita & $\begin{array}{l}12.321 \\
(0.211)\end{array}$ & $\begin{array}{l}7.917^{\mathrm{a}} \\
(0.001)\end{array}$ & $\begin{array}{l}0.377 \\
(0.748)\end{array}$ & $\begin{array}{l}2.199^{a} \\
(0.001)\end{array}$ & $\begin{array}{l}-8.834 \\
(0.210)\end{array}$ & $\begin{array}{l}5.303 \\
(0.120)\end{array}$ & $\begin{array}{l}8.467 \\
(0.331)\end{array}$ & $\begin{array}{l}12.889 \\
(0.112)\end{array}$ \\
\hline Inflation & $\begin{array}{l}-0.002^{c} \\
(0.063)\end{array}$ & $\begin{array}{l}0.000 \\
(0.868)\end{array}$ & $\begin{array}{l}-0.018 \\
(0.317)\end{array}$ & $\begin{array}{l}-0.070^{\mathrm{b}} \\
(0.045)\end{array}$ & $\begin{array}{l}0.000 \\
(0.946)\end{array}$ & $\begin{array}{l}-0.002 \\
(0.930)\end{array}$ & $\begin{array}{l}0.375 \\
(0.214)\end{array}$ & $\begin{array}{l}-0.149^{b} \\
(0.044)\end{array}$ \\
\hline $\begin{array}{l}\text { Agriculture value } \\
\text { added }\end{array}$ & $\begin{array}{l}-0.498^{\mathrm{b}} \\
(0.014)\end{array}$ & $\begin{array}{l}0.038 \\
(0.316)\end{array}$ & $\begin{array}{l}-0.100^{b} \\
(0.032)\end{array}$ & $\begin{array}{l}0.065^{c} \\
(0.072)\end{array}$ & $\begin{array}{l}-0.169^{c} \\
(0.072)\end{array}$ & $\begin{array}{l}-0.017 \\
(0.778)\end{array}$ & $\begin{array}{l}0.116 \\
(0.930)\end{array}$ & $\begin{array}{l}0.012 \\
(0.959)\end{array}$ \\
\hline $\begin{array}{l}\text { Voice and } \\
\text { accountability }\end{array}$ & $\begin{array}{l}2.267 \\
(0.508)\end{array}$ & $\begin{array}{l}3.128 \\
(0.274)\end{array}$ & $\begin{array}{l}-1.910 \\
(0.107)\end{array}$ & $\begin{array}{l}5.839 \\
(0.116)\end{array}$ & $\begin{array}{l}0.275 \\
(0.739)\end{array}$ & $\begin{array}{l}5.950^{\mathrm{a}} \\
(0.006)\end{array}$ & $\begin{array}{l}1.458^{\mathrm{b}} \\
(0.040)\end{array}$ & $\begin{array}{l}2.763^{b} \\
(0.037)\end{array}$ \\
\hline Constant & $\begin{array}{l}55.536 \\
(0.341)\end{array}$ & $\begin{array}{l}18.696^{b} \\
(0.040)\end{array}$ & $\begin{array}{l}1.821 \\
(0.842)\end{array}$ & $\begin{array}{l}11.202^{b} \\
(0.024)\end{array}$ & $\begin{array}{l}8.148^{\mathrm{a}} \\
(0.000)\end{array}$ & $\begin{array}{l}5.236^{\mathrm{b}} \\
(0.023)\end{array}$ & $\begin{array}{l}8.319 \\
(0.423)\end{array}$ & $\begin{array}{l}7.347 \\
(0.695)\end{array}$ \\
\hline $\operatorname{AR}(1)$ & & 0.000 & & 0.000 & 0.385 & 0.000 & & 0.000 \\
\hline $\operatorname{AR}(2)$ & & 0.340 & & 0.093 & & 0.389 & & 0.224 \\
\hline Sargan & & 0.333 & & 0.345 & & 0.257 & & 0.119 \\
\hline
\end{tabular}




\section{Abbreviations}

$A R(1)$ : First order autoregressive; AR(2): Second order autoregressive; FDI: Foreign direct investment; FEM: Fixed effect model; GDP: Gross domestic product; GMM: Generalized Method of Moment; LSDV: Least square dummy variable; MNCs: Multinational corporations; WDI: World Development Indicators; WGI: World Governance Indicators

\section{Acknowledgements}

We thank our respected reviewers for their valuable comments and suggestions that really helped us to improve this paper.

\section{Funding}

We have not taken any fund from any organization.

\section{Availability of data and materials}

We have used secondary data available in the World Development Indicators and World Governance Indicators. All the data used in this paper are downloaded from WDI and WGI.

\section{Authors' contributions}

SS has done introduction, methodology, and results and discussion sections while AR has worked on literature review and theoretical framework. KA has revised the methodology section. All authors read and approved the final manuscript.

\section{Competing interests}

The authors declare that they have no competing interests.

\section{Publisher's Note}

Springer Nature remains neutral with regard to jurisdictional claims in published maps and institutional affiliations.

\section{Author details}

${ }^{1}$ Kashmir Institute of Economics, University of Azad Jammu \& Kashmir, Muzaffarabad, Azad Kashmir, Pakistan.

${ }^{2}$ Department of Statistics, University of Azad Jammu \& Kashmir, Muzaffarabad, Pakistan.

Received: 9 December 2017 Accepted: 18 January 2019

Published online: 16 February 2019

\section{References}

Acemoglu D, Robinson J, Johnson S (2006) Institutions as a fundamental cause of long-run growth. Hand book of economic growth, p 385

Acemoglu D, Verdier T (1998) Property rights, corruption and the allocation of talent: a general equilibrium approach. Econ J 108:1381-1403

Alesina A, Ozler S, Roubini N, Swagel P (1996) Political instability and economic growth. J Econ Growth 1:189-211

Ali FA, Fiess N, MacDonald R (2010) Do institutions matter for foreign direct investment? Open Econ Rev 21(2):201-219

Arellano M, Bond S (1991) Some tests of specification for panel data: Monte Carlo evidence and an application to employment equations. Rev Econ Stud 58(2):277-297

Asamoah ME, Adasi CKD, Alhassan AL (2016) Macroeconomic uncertainty, foreign direct investment and institutional quality: evidence from sub-Saharan Africa economic system, vol 40, pp 612-621

Asiedu E (2002) On the determinants of foreign direct investment to developing countries: is Africa different? World Dev 30(1):107-119

Bénassy-Quéré A, Coupet M, Mayer T (2007) Institutional determinants of foreign direct investment. World Econ 30(5):764-782

Blundell R, Bond S (1998) Initial conditions and moment restrictions in dynamic panel data models. J Econ 87(1):115-143

Brada JC, Kutan AM, Yigit TM (2006) The effects of transition and political instability on foreign direct investment inflows. Econ Transit 14(4):649-680

Bruno M, William E (1996) Inflation and Growth: In Search of a Stable Relationship. Federal Reserve Bank of St. Louis Review; 78(3):139-46

Buchanan BG, Le QV, Rishi M (2012) Foreign direct investment and institutional quality: some empirical evidence. Int Rev Financ Anal 21:81-89

Busse M, Hefeker C (2007) Political risk, institutions and foreign direct investment. Eur J Polit Econ 23(2):397-415

Campos NF, Kinoshita Y, (2008) Foreign direct investment and structural reforms: Evidence from Eastern Europe and Latin America, IMF Working Paper, WP/08/26

Chenaf-Nicet D, Rougier E (2016) The effect of macroeconomic instability on FDI flows: a gravity estimation of the impact of regional integration in the case of Euro-Mediterranean agreements. Int Econ 145:66-91

Culem CG (1988) The locational determinants of direct investments among industrialized countries. Eur Econ Rev 32:885-904

Daude C, Stein E (2007) The quality of institutions and foreign direct investment. Econ Polit 19(3):317-344

David R, Brierley JEC (1985) Major legal systems in the world today. Stevens \& Sons, London

Dunning JH (1988) The eclectic paradigm of international production: a restatement and some possible extensions. J Int Bus Stud 19(1):1-31

Dunning JH (1998) Location and the multinational enterprise: a neglected factor? J Int Bus Stud 29(1):45-66

Dunning, J H (2006). Towards a new paradigm of economic development: implications for the determinants of international business activity. Transnational Corporations 15(1):173-227

Egger P, Winner H (2005) Evidence on corruption as an incentive for foreign direct investment. Eur J Polit Econ 21(4):932-952

Fazio G, Talamo GMC (2008) How "attractive" is good governance for FDI? In: Jay Choi J, Dow S (eds) Institutional approach to global corporate governance: business systems and beyond (international finance review, volume 9). Emerald Group Publishing Limited, pp 33-54. 
Fedderke JW, Romm AT (2006) Growth impact and determinants of foreign direct investment into South Africa, 1956-2003. Econ Model 23(5):738-760

Furceri D, Borelli S (2008) Foreign direct investments and exchange rate volatility in the EMU neighborhood countries. J Int Glob Econ Stud 7(1):42-59

Gani A (2007) Governance and foreign direct investment links evidence from panel data estimations. Appl Econ Lett 14:753-756

Globerman S, Shapiro D (2002) Global foreign direct investment flows: the role of governance infrastructure. World Dev 30(11):1899-1919

Harms P, Ursprung HW (2002) Do civil and political repression really boost foreign direct investments? Econ Ing 40(4):651-663

Hoff K, Stiglitz JE (2005) The creation of the rule of law and the legitimacy of property rights: the political and economic consequences of a corrupt privatization, policy research working paper series 3779. The World Bank, Washington DC

Holland D, Pain N, (1998a) The diffusion of innovations in central and eastern Europe: a study of the determinants and impact of foreign direct investment, NIESR Discussion Paper No. 137

Holland D, Pain N (1998b) The determinants and impact of foreign direct investment in the transition economies: a panel data analysis. In: Edwards V (ed) Convergence or divergence: aspirations and reality in central and eastern Europe and Russia, Proceedings 4th Annual conference, Centre for Research into East European Business, University of Buckingham

IADB (2001). The Business of Growth. Economic and Social Progress in Latin America. 2001 Report. Washington, DC: Johns Hopkins University Press

Kaufmann D, Kraay A, Mastruzzi M (2007) Governance matters VI: governance indicators for 1996-2006. WB, pp 42-80

Khadaroo AJ, Seetanah B (2010) Transport infrastructure and foreign direct investment. J Int Dev 22:103-123

King RG, Levine R (1993) Finance and growth: Schumpeter might be right. Q J Econ 108(3):717-737

Knack S, Keefer P (1995) Institution and economic performance: cross country tests using alternative institutional measures. Econ Polit 7:207-228

Koopmans TC (1965) On the concept of optimal economic growth. In: Study week on the econometric approach to development planning. North-Holland, Amsterdam, pp 225-300

Kravis IB, Lipsey R (1982) The location of overseas production and production for exports by U.S. multinational firms. J Int Econ 12:201-223

La Porta R, Lopez-de Silanes F, Shleifer A, Vishny RW (1997) Legal determinants of external finance. J Financ 52(3):1131-1150

Liargovas PG, Skandalis KS (2012) Foreign direct investment and trade openness: the case of developing economies. Soc Indic Res 106:323-331

Lipsey RE (2001) Foreign direct investors in three financial crises. NBER Working Paper No. 8084. National Bureau of Economic Research, Cambridge

Lucas RE (1993) On the determinants of direct foreign investment: evidence from east and Southeast Asia. World Dev 21(3): 391-406

Lucke N, Eichler S (2016) Foreign direct investment: the role of institutional and cultural determinants. Appl Econ 48(11):935-956

Mauro P (1995) Corruption and growth. Q J Econ 110:681-712

Meier L (2006) Factors driving U. S foreign direct investment. Washington University in ST. Louis, Center for Research in Economics \& Strategy, USA

Mengistu AA, Adhikary BK (2011) Does good governance matter for FDI inflows? Evidence from Asian economies. Asia Pac Bus Rev 17:281-299

North D (1990) Institutions, Institutional Change and Economic Performance, Cambridge: Cambridge University Press

North DC, Thomas RP (1973) The rise of the western world: a new economic history. Cambridge University Press, Cambridge

Peres M, Ameer W, Xu H (2018) The impact of institutional quality on foreign direct investment inflows: evidence for developed and developing countries. Econ Res 31(1):626-644

Saadatmand Y, Choquette J (2012) Neo-liberal policy and foreign direct investment in Africa. Int J Bus Soc Sci 3(17):1-8

Sabir S, Khan A (2018) Impact of political stability and human capital on foreign direct investment in East Asia \& Pacific and south Asian countries. Asian J Econ Model 6(3):245-256

Sabir S, Zahid K (2012) Macroeconomic policies and business cycle: the role of institutions in selected SAARC countries. Pak Dev Rev 51(4):147-160

Schneider F, Frey BS (1985) Economic and political determinants of foreign direct investment. World Dev 13:161-175

Shah MH, Khan Y (2016) Trade liberalisation and FDI inflows in emerging economies. Bus Econ Rev 8(1):35-52

Solow RM (1956) A contribution to the theory of economic growth. Q J Econ 70(1):65-94

Tondl G, Fornero JA, (2010) Sectoral productivity and spillover effects of FDI in Latin America, FIW Working Paper Series 053

Ullah I, Khan MA (2017) Institutional quality and foreign direct investment inflows: evidence from Asian countries. J Econ

Stud 44(5):833-860

World Bank (2013) World development indicators, World Bank database, Washington DC 